\title{
First Record of the Pink Lipped Moray Eel, Echidna rhodochilus (Bleeker 1863) (Family: Muraenidae), from Andaman and Nicobar Islands, India
}

\author{
M. Arun Kumar, S. Venu, and G. Padmavati \\ Department of Ocean Studies and Marine Biology, Pondicherry University, Brookshabad Campus, Post Bag No. 26, \\ Chakkargaon Post, Port Blair, Andaman Islands 744112, India
}

Correspondence should be addressed to M. Arun Kumar; arun4kavi@gmail.com

Received 30 March 2016; Accepted 14 June 2016

Academic Editor: Heinrich Hühnerfuss

Copyright (C) 2016 M. Arun Kumar et al. This is an open access article distributed under the Creative Commons Attribution License, which permits unrestricted use, distribution, and reproduction in any medium, provided the original work is properly cited.

The paper is the first record of the occurrence of the Pink Lipped Moray Eel, Echidna rhodochilus (Bleeker 1863), from India. The current specimen was caught from the mangrove creeks of Carbyn's Cove, South Andaman. This species is known so far from Western Pacific and southeastern Indian Ocean up to Australia and Indonesia. The present study indicates that there are more studies to be conducted on the ichthyofauna of these islands for a better understanding of the biodiversity of this area.

\section{Introduction}

The Andaman and Nicobar Islands have unique ecosystems, mainly contributed by coral reefs, mangroves, seagrass, and seaweed beds as shelters and feeding grounds for many species. The Andaman and Nicobar fish fauna consists of an assemblage of about 1463 species spread over all the diverse habitats representing 586 genera belonging to 175 families. The fish diversity in Andaman and Nicobar Islands is of special interest in terms of marine zoogeography because of the confluence in the fishes of Andaman Sea with those of the Western Pacific and the Indian Ocean [1].

The family Muraenidae belongs to the order Anguilliformes. It contains 15 genera and 300 species [2]. The name of the family comes from the "Latin" word Muraena meaning moray eel [3]. Moray eels are cosmopolitan, most of them exclusively in marine, but several species are regularly seen in brackish water, and a few can sometimes be found in fresh water. They are mainly characterized by a very elongate muscular compressed body with a large mouth. Most have long sharp canine teeth but some such as the species belonging to Echidna have low nodular teeth. The species of Echidna prey principally on crustaceans, especially crabs, for which their blunt crushing teeth are well suited. The dorsal fin extends from just behind the head along the back and joins seamlessly with the caudal and anal fins. All the species lack pectoral and pelvic fins, adding to their serpentine appearance. Their eyes are rather small; morays rely on their highly developed sense of smell, lying in wait to ambush prey. The muraenid eels are often regarded as being nocturnal, but only few species actively forage for food at night [4].

So far, 20 species of muraenids have been reported from Andaman and Nicobar Islands, representing 8 genera (Echidna, Muraena, Gymnomuraena, Gymnothorax, Rhinomuraena, Scuticaria, Strophidon, and Uropterygius). Echidna nebulosa was the only species from the genus Echidna previously reported from Andaman and Nicobar Islands [1].

\section{Materials and Methods}

During an ichthyofaunal survey in the mangrove creeks of Carbyn's Cove near Port Blair (Figure 1), fishes were collected by using hook and line. The species was identified following standard identification keys $[5,6]$. A detailed literature survey has revealed that the species Echidna rhodochilus was not recorded earlier from Andaman and Nicobar Islands [1,7-11]. The morphometric and meristic characteristics were analysed and discussed. 


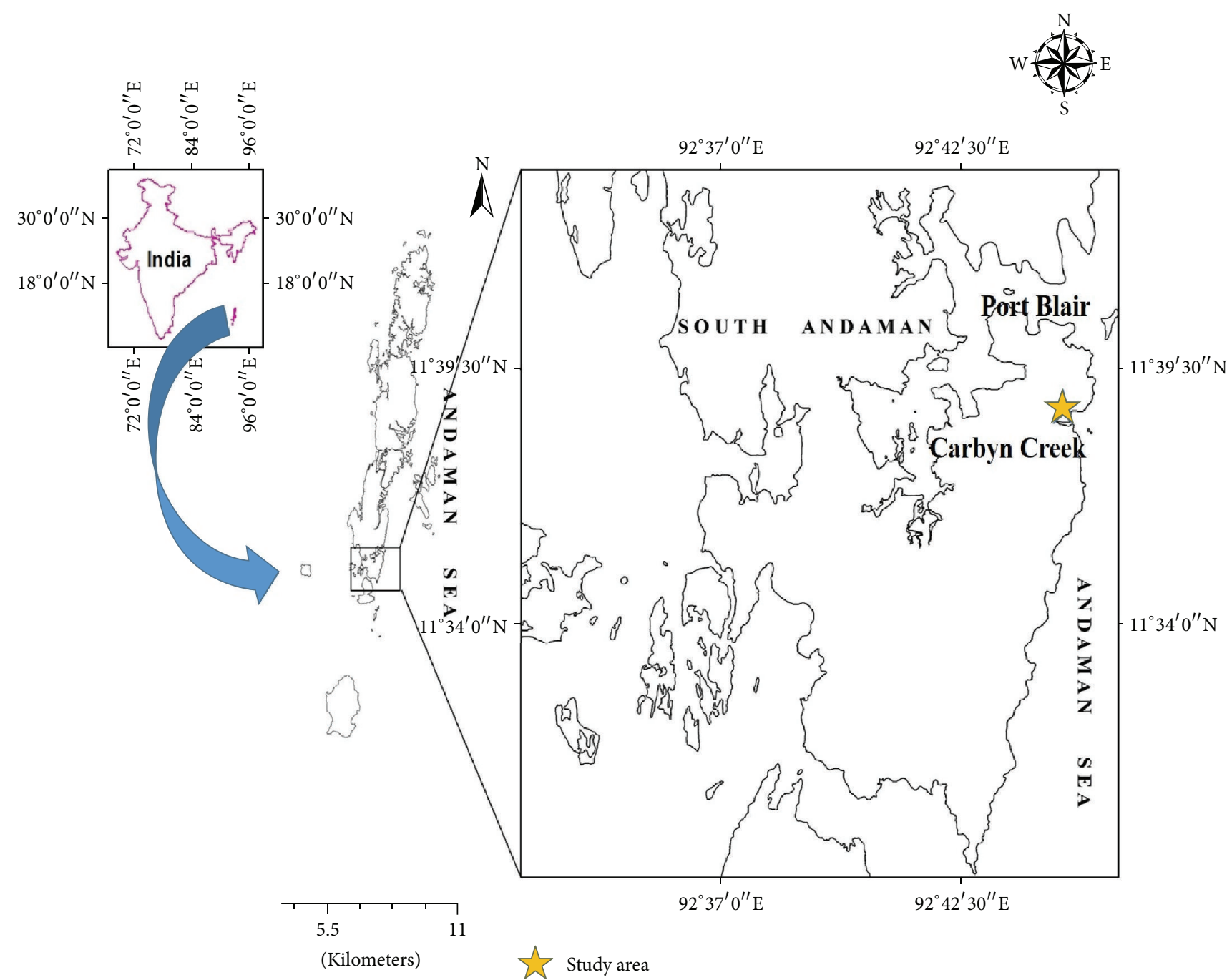

FIgURE 1: Study area map.

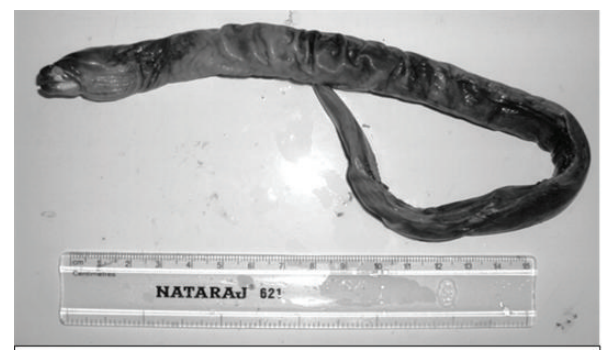

FIGURE 2: Echidna rhodochilus.

\section{Results}

The newly recorded species was identified as Echidna rhodochilus Bleeker 1863, commonly called Freshwater Moray Eel or Pink Lipped Moray Eel, L. S. Berg, 1940 (Figure 2).

\section{Systematics}

Kingdom: Animalia Linnaeus, 1758

Phylum: Chordata Haeckel, 1874
Class: Actinopterygii Klein, 1885

Order: Anguilliformes L.S. Berg, 1940

Family: Muraenidae Rafinesque, 1810

Genus: Echidna Forster, 1777

Species: rhodochilus Bleeker 1863

Echidna rhodochilus Bleeker. Ned. Tijdshr.Dierk. I, 1863, p.247.-Atl. Icth, IV, 1864, p79.

\section{New Combination}

Muraena rhodochilus, Günther. Cat.Brit.Mus.VIII, 1870, p.132.

Common Name. Freshwater Moray Eel or Pink Lipped Moray Eel.

Two specimens, $326 \mathrm{~mm}$ and $324 \mathrm{~mm}$ TL, males, were collected by Arun Kumar. M, on February 13, 2010, from the mangrove creek in Carbyn's Cove, around $5 \mathrm{~km}$ from Port 
TABLE 1: Comparative meristic counts and measurements of Echidna rhodochilus and Echidna nebulosa.

\begin{tabular}{|c|c|c|c|c|}
\hline $\begin{array}{l}\text { Morphometric measurements } \\
\text { and meristic characters }(\mathrm{mm})\end{array}$ & $\begin{array}{l}\text { E. rhodochilus specimen } 1 \\
\text { from Port Blair }\end{array}$ & $\begin{array}{l}\text { E. rhodochilus specimen } 2 \\
\text { from Port Blair }\end{array}$ & E. rhodochilus [5] & $\begin{array}{c}\text { E. nebulosa from } \\
\text { Port Blair }\end{array}$ \\
\hline Total length\% & 326 & 324 & 338 & 248 \\
\hline Head length & 11.66 & 11.11 & - & 11.29 \\
\hline Predorsal length & 17.79 & 17.28 & - & 10.08 \\
\hline Snout length & 3.07 & 3.09 & - & 2.82 \\
\hline Postorbital length & 9.51 & 9.57 & - & 9.27 \\
\hline Eye diameter & 1.23 & 0.93 & - & 0.81 \\
\hline Preorbital length & 1.53 & 1.54 & - & 2.02 \\
\hline Upper jaw length & 3.68 & 3.40 & - & 4.44 \\
\hline Lower jaw length & 3.68 & 3.40 & - & 3.63 \\
\hline Anal length & 52.15 & 51.85 & - & 40.32 \\
\hline Body depth & 5.52 & 5.56 & 5.62 & 3.23 \\
\hline Head depth & 5.83 & 5.56 & 5.33 & 5.24 \\
\hline Depth at anus & 6.13 & 5.56 & - & 4.84 \\
\hline Head length\% & 38 & 36 & - & 28 \\
\hline Snout length & 26.32 & 27.78 & - & 25 \\
\hline Postorbital length & 81.58 & 83.33 & - & 82.14 \\
\hline Eye diameter & 7.89 & 8.33 & - & 7.14 \\
\hline Preorbital length & 13.16 & 13.89 & - & 17.86 \\
\hline Upper jaw length & 28.95 & 30.56 & - & 39.29 \\
\hline Lower jaw length & 28.95 & 30.56 & - & 32.14 \\
\hline
\end{tabular}

Blair, Andaman and Nicobar Islands. The identified specimen was preserved in 5\% formalin and deposited in the fishery museum, Department of Ocean Studies and Marine Biology, Pondicherry University, Port Blair (PU/DOSMB/2010/2/1).

4.1. Comparative Material Examined. A specimen of Echidna nebulosa (Ahl, 1789) from the nearby areas of Carbyn's Cove was compared with E. rhodochilus. E. nebulosa has been the only species in the genus reported from this area so far. The body is moderately elongate and compressed along the tail. The head has a steep profile, and the snout is short and blunt; the eye is relatively small; the anterior nostril is a short tube and the posterior nostril is a simple hole with a raised rim, above and before the eye. The colour is variable, but typically yellowish-brown with 2 or 3 longitudinal series of darker, starshaped spots along the body, each with a yellow center; the spots variably combined to form vertical bands; smaller spots and mottlings occur between the starry blotches. No pink spot is found on the cheek.

4.2. Diagnosis. E. rhodochilus and E. nebulosa present a marked colour difference, the former being brown in colour and the latter with star-shaped mottled blotches. There is a pink spot on the cheek in E. rhodochilus which is absent in $E$. nebulosa.

\subsection{Key for the Genus Echidna. Genus Echidna Forster, 1777}

(1a) E. nebulosa: pale body with two rows of star-like blotches with centers.

(1b) E. rhodochilus: dorsal fin origin behind gill opening; brown body with darker reticulations; head pores and

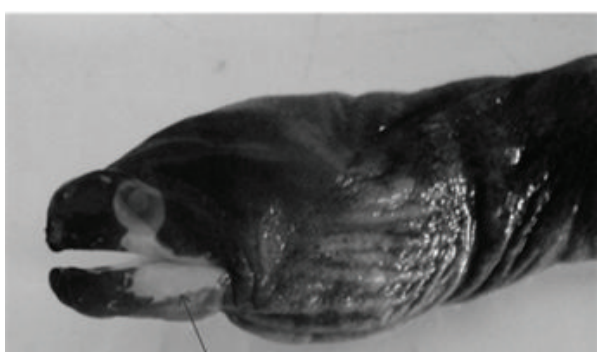

FIGURE 3: Pink spot on the cheek.

posterior nostril in small white spots; white blotch on jaws below eye, larger on lower jaw (Figure 3).

\section{Description}

Characteristically, moray has an elongate, slender, snake-like body, a large mouth, median fins confluent with caudal fin, and no pelvic and pectoral fins. Gill opening is small and round. Head and trunk are equal to or somewhat shorter than the tail. The body is scaleless.

The origin of the dorsal fin is slightly behind gill openings and fleshy. Teeth are obtusely conical, in the maxillaries in 2 series, the outer with 14 and the inner with 9 teeth. In the lower jaw posteriorly a series of about 12 teeth is present and anteriorly two series of 6 pairs of teeth are present, the inner of which are stouter. On the vomer, two complete and one irregular series of strong teeth are found; on the intermaxillary plate a broad, nearly oval group of teeth are found, with the outer series much smaller than the 12 much 
stouter inner ones. It is brownish black with yellow fins. The specimen preserved in formalin (5\%) is dark reddish brown with a whitish pink spot on the upper and lower lips near the corner of the mouth; with this marking, this species can be easily identified.

5.1. Remarks. The morphometric characteristics of the present specimen are similar to specimens reported from Indonesia [12] and significantly differ from those of Echidna nebulosa collected from Port Blair (Table 1). It has a blunt head compared to other well-known morays and is one of the smaller fish of the group. Maximum length is reported up to $33.8 \mathrm{~cm}[12]$.

5.2. Habit and Habitat. Adults are benthic, generally in shallow water among rocks and corals; they are mainly nocturnal and hide in holes and crevices during the day. They feed mainly on crustaceans, cephalopods, and small fishes. Primarily, a marine species yet shows a wide range of distribution, also found in brackish and freshwater environments. Some members of this family are used in the aquarium trade [13].

\section{Distribution}

The species is found in the Indo-West Pacific region: Indonesia and the Philippines $[5,14]$, Papua New Guinea to New Zealand [15], and Japan to Fiji [16, 17].

\section{Conclusion}

By comparison with a similar species occurring in the same area and by referring to available literature on the muraenid fishes of Andaman Islands, the specimen was identified and confirmed as Echidna rhodochilus and is reported for the first time from India.

\section{Competing Interests}

The authors declare that there is no conflict of interests regarding the publication of this paper.

\section{Acknowledgments}

The authors acknowledge sincerely the help rendered by the fisherman Mr. Dhanapal (Babu), who aided the authors in collecting the samples. The authors are indebted to Mr. A. Saravanan, Department of Disaster Management, Pondicherry University, for preparing the map of the study area.

\section{References}

[1] I. T. Ramakrishna, C. R. Sreeraj, C. Ragunathan, R. Raghuraman, P. T. Rajan, and J. S. Yogeshkumar, "An account of additions to the Ichthyofauna of Andaman and Nicobar Islands. Records of Zool. Surv. India," Occasional Paper 326:1-140, 2010.

[2] G. Smith David, "A checklist of the moray eels of the world (Teleostei: Anguilliformes: Muraenidae)," Zootaxa, vol. 3474, pp. 1-64, 2012.

[3] E. B. Böhlke, J. E. McCosker, and D. G. Smith, "Muraenidae," in FAO Species Identification Guide for Fishery Purposes. The Living
Marine Resources of the Western Central Pacific, K. E. Carpenter and V. H. Niem, Eds., vol. 3 of Batoid Fishes, Chimaeras and Bony Fishes Part 1 (Elopidae to Linophrynidae), FAO, Rome, Italy, 1999.

[4] J. E. Randall, G. R. Allen, and R. C. Steene, Fishes of the Great Barrier Reef and Coral Sea, Crawford House Publishing, Bathurst, Australia, 2nd edition, 1997.

[5] M. Weber and L. F. De Beafort, The Fishes of the Indo-Australian Archipelago. Vol-III. Ostariophysi: II Cyprinoidea, Apodes, Synbranchi, E J Brill Ltd, Leiden, the Netherlands, 1916.

[6] W. Fischer and W. Bianchi, Eds., FAO Species Identification Sheets for Fishery Purposes, Western Indian Ocean; (Fishing area, 51), (Prepared and Printed with the Support of the Danish International Development Agent (DANIDA), vol. 1-6, Food and Agricultural organization of the United Nations, Rome, Italy, 1984.

[7] A. W. C. T. Herre, "A list of the fishes known from the Andaman Islands," Memoirs of Indian Museum, vol. 13, no. 3, pp. 331-403, 1939.

[8] P. K. Talwar, "Fishes of the Andaman and Nicobar Islands: a synoptic analysis," Journal of Andaman Science Association, vol. 6, no. 2, pp. 1-12, 1990.

[9] D. V. Rao, K. Devi, and P. T. Rajan, "An account of ichthyofauna of Andaman and Nicobar Islands, Bay of Bengal," Records of the Zoological Survey of India, Occasional Paper 178, 2000.

[10] K. Devi and D. V. Rao, "Mangrove ichthyofauna of Andaman and Nicobar Islands," Records of the Zoological Survey of India, Occasional Paper 265, 2007.

[11] P. Vijay and D. Priya, "A survey of freshwater fishes of Andaman Islands," Journal of Bombay Natural History Society, vol. 106, no. 1, pp. 264-267, 2000.

[12] M. Kottelat, A. J. Whitten, S. N. Kartikasari, and S. Wirjoatmodjo, Freshwater fishes of Western Indonesia and Sulawesi, Periplus Editions, Jakarta, Indonesia, 1993.

[13] P. J. Kailola, The Fishes of Papua New Guinea. A Revised and Annotated Checklist, vol. 1 of Myxinidae to Synbranchidae, Research Bulletin no. 41, Department of Fisheries and Marine Resources, Port Moresby, Papua New Guinea, 1987.

[14] A. W. C. T. Herre, "Check list of Philippine fishes," Research Report of U.S. Fish Wildlife Service 20, 1953.

[15] G. R. Allen and P. L. Munday, "Kimbe Bay rapid ecological assessment: the coral reefs of Kimbe Bay (West New Britain, Papua New Guinea)," in Fish Diversity of Kimbe Bay, G. R. Allen and P. L. Munday, Eds., The Nature Conservancy, South Pacific program Office, Auckland, New Zealand, 1994.

[16] K. Hatooka, H. Senou, and M. Aizawa, "New records of the moray Echidna rhodochilus (Muraenidae, Anguilliformes) from Japan and Fiji Islands," I.O.P. Diving News, vol. 3, no. 4, pp. 2-3, 1992.

[17] T. Nakabo, Fishes of Japan with Pictorial Keys to the Species, Tokai University Press, 2002. 

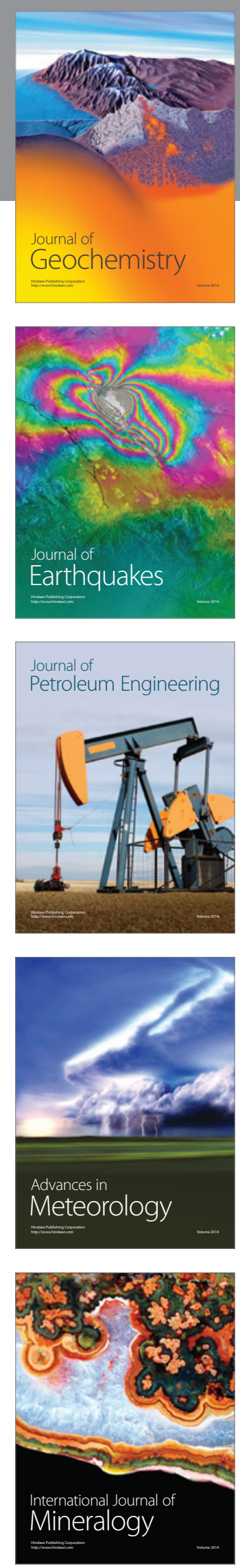
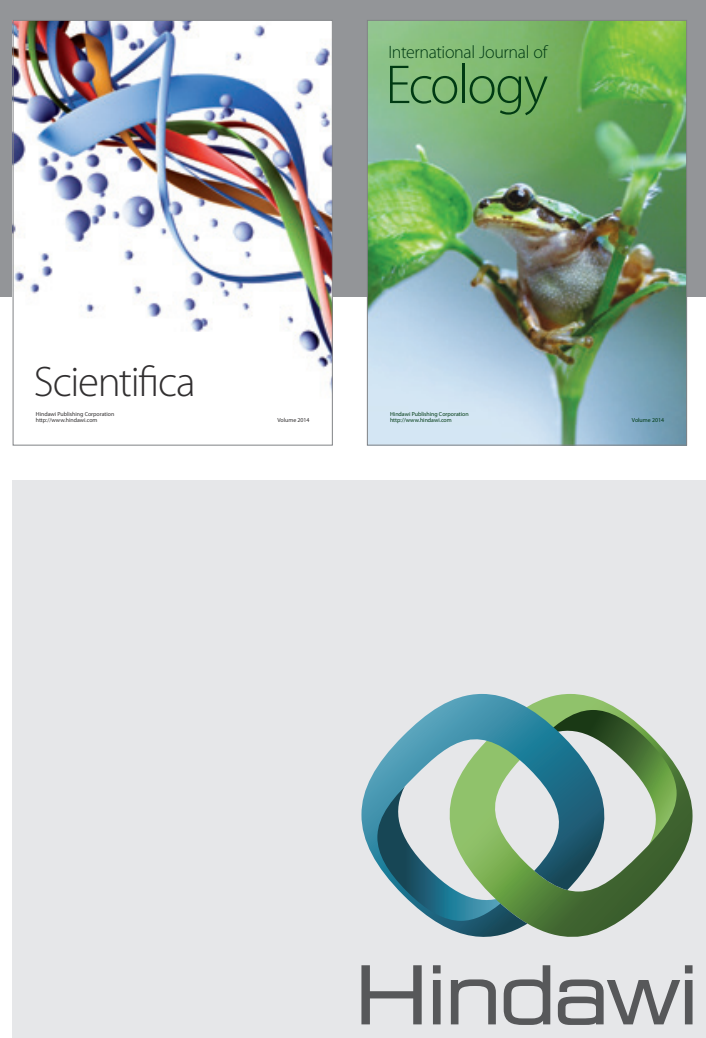

Submit your manuscripts at

http://www.hindawi.com
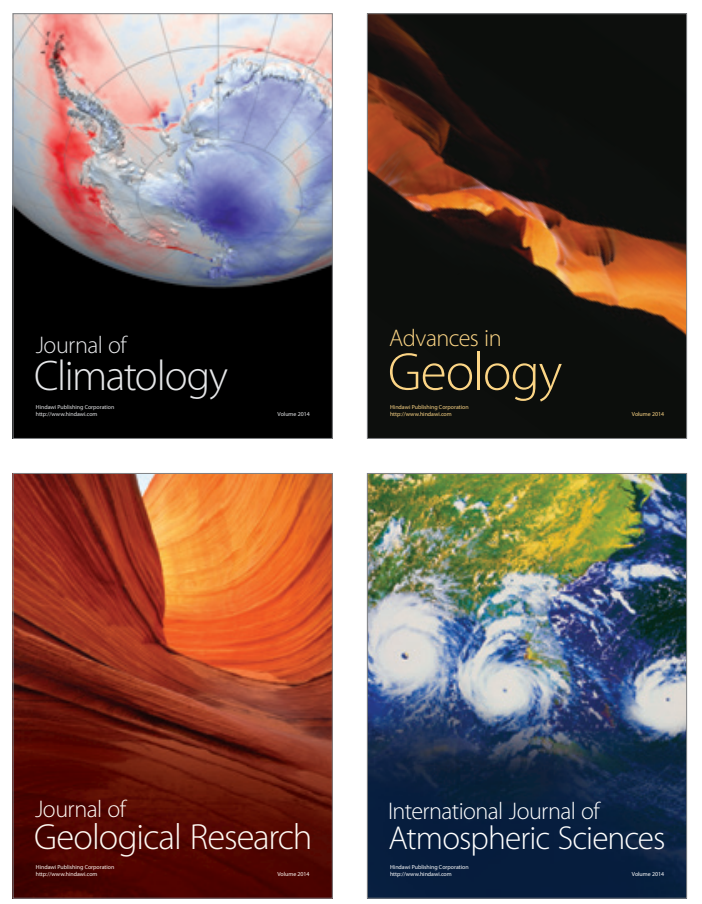

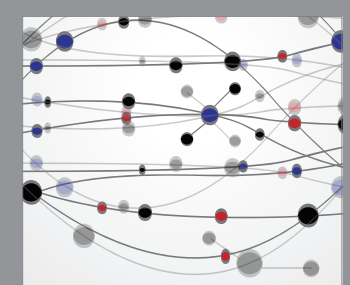

The Scientific

\section{World Journal}
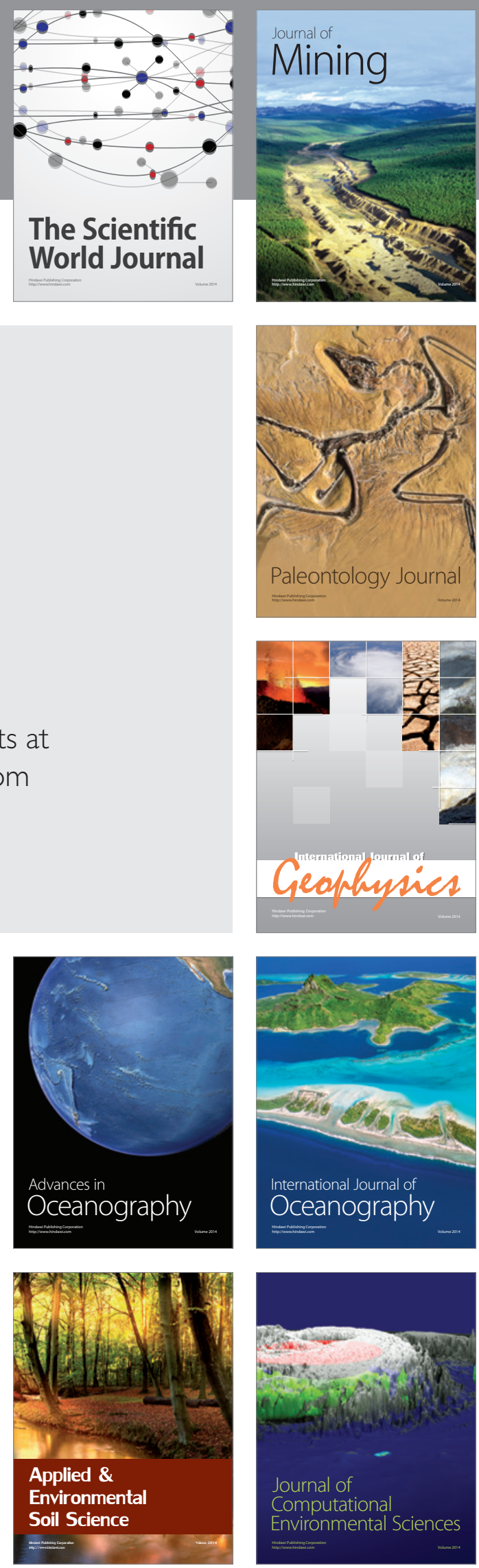